\title{
ARTICLES
}

\section{Talons and beaks are viable but underutilized samples for detecting organophosphorus and carbamate pesticide poisoning in raptors}

\author{
Ngaio Richards ${ }^{1,5^{*}}$, Irene Zorrilla ${ }^{2}$, Joseph Lalah $^{3}$, Peter Otieno ${ }^{4}$, Isabel \\ Fernandez $^{2}$, Monica Calvino ${ }^{2}$ and Joaquin Garcia ${ }^{2}$ \\ ${ }^{1}$ Working Dogs for Conservation, PO Box 280, Bozeman, Montana 59771, USA \\ ${ }^{2}$ Environmental and Water Agency of Andalusia, Division of Integrated Environmental \\ Quality. Regional Ministry of Environment and Spatial Planning, Center for Analysis \\ and Diagnosis of Wildlife - CAD, Avda. Lope de Vega, 9, Málaga 29010, Spain. \\ ${ }^{3}$ Kenya Polytechnic University College, Department of Chemical Science and \\ Technology, Technical University of Kenya, Nairobi, Kenya \\ ${ }^{4}$ Pest Control Products Board, PO Box 2757, Kisumu, Kenya \\ ${ }^{5}$ William R. Maples Center for Forensic Medicine, Department of Pathology, \\ Immunology and Laboratory Medicine, University of Florida, Gainesville, Florida \\ 32608, USA \\ *Corresponding author: ngaio@wd4c.org
}

http://dx.doi.org/10.4314/vulnew.v72i1.1

\begin{abstract}
In Europe and Africa, birds of prey, particularly vultures, are being secondarily or intentionally poisoned with acutely toxic concentrations of organophosphorus (OP) and carbamate (CM) pesticides in baited food items. By the time a mortality incident is discovered, few or no fresh carcasses, considered optimal for toxicological analysis, remain. Regardless, residues are not always detectible in typically analyzed samples (e.g., liver) because death can occur so rapidly. Without concrete forensic evidence to implicate the compounds being used and an intent to poison, ongoing local mitigation and regulatory efforts will continue to be undermined. We have sought additional means of gathering information about deliberate wildlife poisoning by testing the feasibility of detecting residues in decomposed carcasses that would not
\end{abstract}


otherwise be analyzed. As likely first points of contact with poisoned food items, talons and beaks may contain detectible residues. Here, we report on the analysis of talon $(n=9)$ and beak $(n=7)$ samples conducted at the Center for Analysis and Diagnosis of Wildlife (CAD) in southern Spain from 20122016. Aldicarb and metabolites, methomyl and chlorfenvinphos were detected in talon samples, whereas aldicarb, chlorpyrifos and carbofuran were detected in the beaks. In several instances, the talon or beak was the only sample taken from a carcass that tested positive. We suggest that not recovering talons or heads/beaks from the field for analysis, especially in the absence of other viable carcass components, may result in pesticide residues - and deliberate poisoning incidents - being overlooked.

In North America, avian mortality/debilitation related to organophosphorus (OP) or carbamate $(\mathrm{CM})$ pesticide exposure is commonly associated with exposure during agricultural applications (Mineau et al. 2012b). In this context, inhibition of brain cholinesterase (acetylcholinesterase; $\mathrm{AChE}$ ) activity is used as a diagnostic marker for determining avian exposure, in conjunction with confirmatory detection of residues in samples such as the liver or stomach contents (Henny \& Elliott 2007, Hill \& Fleming 1982, Mineau et al. 2012a). Given these analytical parameters, tissues from recent or 'fresh' carcasses are viewed as optimal samples for toxicological analyses (Richards et al. 2014).

Here, we address a deliberate and illegal poisoning exposure context. In Europe and Africa, wildlife species perceived to be in competition with hunters or that threaten crops or livestock are intentionally being poisoned with extremely concentrated levels of OP and $\mathrm{CM}$ pesticides, and avian scavengers - particularly Old World Vultures - are suffering the consequences (Fajardo et al. 2012, Ogada 2014, Ogada et al. 2015). In Africa, avian scavengers are being secondarily poisoned at an alarming rate, by consuming livestock carcasses deliberately laced with OP and $\mathrm{CM}$ pesticides intended for predators, especially lions and, to an even greater extent, hyenas (Otieno et al. 2011, Ogada 2014, Ogada et al. 2015). These compounds are also used to deliberately poison birds for human consumption, whether as food (Odino 2012), or for recovery of their body parts - including heads and feet - which are then sold for 'traditional medicine' or as fetish for enhancing a person's luck or success 
(McKean et al. 2013, Buij et al. 2015). Vultures are now deliberately targeted by poachers who seek to prevent the birds' overhead circling, which rangers and scouts have learned to monitor as an indication of illicit poaching activity (Ogada et al. 2015).

Of all the affected European and African countries, Spain's response has been one of the most rapid, with the government of Andalucía launching an anti-poaching and antipoisoning strategy: the Estrategia Para el Control del Veneno. This has included training and deployment of detection dog-handler teams with the ability to locate any poisoned animal carcass working in partnership with wildlife agents proficient in recovering samples from potential wildlife scenes of crime according to rigorously established protocols. These samples are then submitted to the Center for Analysis and Diagnosis of Wildlife (CAD), where cause of death is determined through a series of comprehensive analyses and evidence of crimes against wildlife is gathered for prosecution of cases (Fajardo et al. 2012).

Sourcing even moderately fresh carcasses for analyses has always posed a significant challenge within the mandate of the Estrategia. Even if a mass avian mortality incident suspected to arise from intentional poisoning is reported promptly, there is still a lag time related to mobilizing the necessary resources and obtaining the required access permissions. Likewise, individuals that succumb to a toxic but sloweracting poison (e.g. chlorpyrifos) may be found away from the source of poisoning (e.g. a baited carcass) in a less conspicuous area, the deterioration of their carcasses facilitated by the ambient climatic conditions. Thus, the poor condition of the majority of the carcasses recovered during these investigation and submitted to CAD precludes analysis of AChE levels (Fajardo \& Zorrilla 2016). Even when fresh carcasses are available, we caution that these compounds can be present in baits at such acutely toxic levels that birds die with the food still in their mouths, either unswallowed or regurgitated, before residues may reach other parts of the body (Richards et al. 2014, Richards et al. 2015, Fajardo \& Zorrilla 2016).

Given these challenging factors, personnel at the CAD have long been interested in assessing the feasibility of detecting residues in samples that coincide with initial (i.e. preingestion) points of contact with poison on a carcass, and that are better able to withstand environmental degradation than tissues (e.g. liver). Our investigations 
have led to the detection of both $\mathrm{CM}$ (e.g. aldicarb) and OP (e.g. chlorfenvinphos) compounds in the palates and tongues of deliberately and/or unintentionally poisoned vultures, canids and domestic animals (Richards et al. 2015). Vyas et al. (2003) detected residues of the OP compound diazinon in (artificially exposed) gosling feet left outside for seven days. Residues of the CM carbofuran were also found in the (artificially exposed) talons of Eastern Screech-owls Megascops asio weathered for 28 days (Vyas $e t$ al. 2005). Otieno et al. (2010) detected residues of carbofuran and its primary metabolites in the talons and beaks of a desiccated African White-backed Vulture Gyps africanus carcass retrieved from an agricultural field in Kenya. In light of these findings, the opportunistic analysis of talons and heads/beaks was also initiated at CAD (Zoun \& Spierenburg 1989, Richards et al. 2015 - Supplemental Information). Table 1 and 2 summarize the OP and $\mathrm{CM}$ compounds (and/or their main breakdown products) that have been detected in the talons and beaks, respectively, of various avian species submitted to the CAD as part of routine wildlife forensics investigations in southern Spain between 2012 and 2016 .

During these years, the talons ( $\mathrm{n}$ $=9)$ and beaks $(n=7)$ in a total of six and five species, respectively, were analyzed at the $\mathrm{CAD}$ for $\mathrm{OP}$, $\mathrm{CM}$, organochlorine (OC) and pyrethroid compounds (as per Zoun \& Spierenburg 1989, see Richards et al. 2015 - Supplemental Information). One OP and two CM compounds were detected in the talons (Table 1), whilst one OP and two CM compounds were identified in the beaks (Table 2). We note that residues of $p, p$ '-DDE were detected in the talons of the Cinereous Vulture Aegypius monachus and Egyptian Vulture Neophron percnopterus (Table 1; 0.05 and 0.25 $\mathrm{mg} / \mathrm{kg}$ ) and the talons of a Griffon Vulture Gyps fulvus in which no other compounds were detected $(0.06 \mathrm{mg} / \mathrm{kg})$. Although these residues are consistent with historical agricultural use of DDT in Spain and other parts of Europe (Fajardo et al. 2012, Muños \& Jiménez 2011), their detection, and by extension that of an OC compound in the talons, is nonetheless relevant where OC pesticides are used to poison wildlife, and in the context of broader environmental monitoring. 
Table 1: Organophosphorus and carbamate residues detected in talons $(n=9)$ of avian carcasses analyzed at the Center for Analysis and Diagnosis of Wildlife (CAD) in southern Spain $(2012$ - 2016)

\begin{tabular}{|c|c|c|c|}
\hline Species & $\begin{array}{c}\text { Pesticide } \\
\text { (and/or } \\
\text { metabolite) } \\
\text { detected }\end{array}$ & $\begin{array}{l}\text { Residue } \\
\text { (mg/kg) }\end{array}$ & Comments \\
\hline \multirow{4}{*}{$\begin{array}{c}\text { Black Kite } \\
\text { Milvus migrans } \\
\mathrm{n}=4\end{array}$} & Aldicarb & NQ & $\begin{array}{l}\text { Also detected in the stomach } \\
\text { contents: } \\
\text { Aldicarb: } 45 \mathrm{mg} / \mathrm{kg} \\
\text { Aldicarb sulfoxide: } 60 \mathrm{mg} / \mathrm{kg}\end{array}$ \\
\hline & $\begin{array}{l}\text { Aldicarb } \\
\text { Aldicarb } \\
\text { Sulfoxide }\end{array}$ & $\begin{array}{l}0.12 \\
0.05\end{array}$ & $\begin{array}{c}\text { Not detected in tissues, palate } \\
\text { or beak }\end{array}$ \\
\hline & $\begin{array}{c}\text { Aldicarb } \\
\text { Aldicarb } \\
\text { sulfoxide } \\
\text { Aldicarb sulfone }\end{array}$ & $\begin{array}{l}0.74 \\
0.57 \\
0.02\end{array}$ & Not detected in the gizzard \\
\hline & Methomyl & 0.04 & $\begin{array}{l}\text { The only positive value } \\
\text { obtained in all samples }\end{array}$ \\
\hline $\begin{array}{c}\text { Cinereous Vulture } \\
\text { Aegypius monachus } \\
\mathrm{n}=1\end{array}$ & Chlorfenvinphos & 0.08 & $\begin{array}{l}\text { Carcass in poor condition, } \\
\text { talons were the only sample } \\
\text { that could be analyzed }\end{array}$ \\
\hline $\begin{array}{c}\text { Egyptian Vulture } \\
\text { Neophron } \\
\text { percnopterus } \\
\mathrm{n}=1\end{array}$ & $\begin{array}{l}\text { Aldicarb } \\
\text { Aldicarb } \\
\text { sulfoxide }\end{array}$ & $\begin{array}{l}0.02 \\
0.02\end{array}$ & $\begin{array}{l}\text { Not detected in crop or } \\
\text { oesophagus }\end{array}$ \\
\hline $\begin{array}{l}\text { Montagu's Harrier } \\
\text { Circus pygargus } \\
\mathrm{n}=1\end{array}$ & Aldicarb & NQ & $\begin{array}{l}\text { Also detected and quantified } \\
\text { in the gizzard: } \\
\text { Aldicarb: } 147 \mathrm{mg} / \mathrm{kg} \\
\text { Aldicarb sulfoxide: } 6 \mathrm{mg} / \mathrm{kg}\end{array}$ \\
\hline $\begin{array}{c}\text { Red Kite } \\
\text { Milvus milvus } \\
\mathrm{n}=1\end{array}$ & Aldicarb & NQ & $\begin{array}{l}\text { Also detected and quantified } \\
\text { in crop: } \\
\text { Aldicarb: } 15.38 \mathrm{mg} / \mathrm{kg} \\
\text { A. sulfoxide: } 0.94 \mathrm{mg} / \mathrm{kg} \\
\text { Gizzard: Aldicarb: } 0.01 \mathrm{mg} / \mathrm{kg}\end{array}$ \\
\hline $\begin{array}{l}\text { Spanish Imperial } \\
\text { Eagle } \\
\text { Aquila adalberti } \\
\mathrm{n}=1\end{array}$ & $\begin{array}{l}\text { Aldicarb } \\
\text { sulfoxide }\end{array}$ & 0.015 & $\begin{array}{l}\text { Not detected in stomach, } \\
\text { palate or beak }\end{array}$ \\
\hline
\end{tabular}

$\mathrm{NQ}=$ not quantified, detected by thin layer chromatography (TLC) 
In some instances, the talon or beak was the only sample in which residues were, or could, be detected. For example, every viable sample was collected from the carcass of the Imperial Eagle Aquila adalberti and analyzed, however only the bird's talons yielded a positive result. Similarly, methomyl was only detected in the talons of a Black Kite Milvus migrans and chlorfenvinphos was only detected in those of a Cinereous Vulture. It also occurred that residues were detected in a bird's beak but not its talons or vice versa and only in the talons.

Though indicative of dermal contact, the presence of $\mathrm{OP} / \mathrm{CM}$ residues on/in an individual's talons (but not the beak) is not conclusive evidence of poison ingestion per se. However, reinforced by expert testimony regarding vulture/scavenger feeding morphology and behaviours in relation to a (poisoned) carcass, this finding is of evidentiary value. And, at least in Spain, the mere detection of an OP and/or CM compound in either of these samples alone would suffice to show intent to poison, and to bring a case to court, in conjunction with the other evidence gathered in situ (Fajardo \& Zorrilla 2016). When the carcasses of multiple species have been recovered, residues detected in either the beak or the talons of one carcass could compel a re-examination of others that had previously tested negative, especially if the latter was of a species accorded a higher protection status. Following a mass vulture poisoning in southern Spain in 2012, the detection of chlorfenvinphos residues in two Griffon Vultures prompted another examination of the carcass of a highly decomposed Cinereous Vulture that was also recovered from the scene (Richards et al. 2015). The bird's palate was removed for analysis, and subsequent detection of chlorfenvinphos in this sample further strengthened the legal justification for pursuing the case and ultimately served as a cornerstone of the secured conviction.

Many of the species from which residues were detected in the talons and beaks (Tables 1 and 2) have been accorded a protected status of 'Endangered' or 'Near Threatened' by the IUCN, such as Egyptian Vulture and Cinereous Vulture and Red Kite Milvus milvus (BirdLife International 2013), which can be used to help secure a conviction and strengthen penalties. Briefly, from an analytical perspective, in all cases where the presence of a $\mathrm{CM}$ or $\mathrm{OP}$ compound was qualitatively established in talons or beaks, via 
thin layer chromatography (TLC), quantitative evidence of the same was also obtained. We note that TLC capacity is often a fixture even in the most minimally equipped laboratory, and therefore, in the absence

of further confirmatory/quantitative analysis, a qualitative analysis could at least be conducted to establish presence/absence of a pesticide.

Table 2: Organophosphorus and carbamate residues detected in beaks $(n=7)$ of avian carcasses analyzed at the Center for Analysis and Diagnosis of Wildlife (CAD) in southern Spain $(2012-2016)$

\begin{tabular}{|c|c|c|c|}
\hline Species & $\begin{array}{c}\text { Pesticide } \\
\text { (and/or } \\
\text { metabolite) } \\
\text { detected }\end{array}$ & $\begin{array}{l}\text { Residue } \\
\text { (mg/kg) }\end{array}$ & Comments \\
\hline \multirow{2}{*}{$\begin{array}{c}\text { Black Kite } \\
\text { Milvus migrans } \\
\mathrm{n}=2\end{array}$} & Carbofuran & 0.30 & $\begin{array}{c}\text { The only positive value } \\
\text { obtained, of all the samples } \\
\text { analyzed }\end{array}$ \\
\hline & Chlorpyrifos & 2.96 & $\begin{array}{l}\text { Also detected in the } \\
\text { stomach: } 2.03 \mathrm{mg} / \mathrm{kg}\end{array}$ \\
\hline $\begin{array}{c}\text { Egyptian Vulture } \\
\text { Neophron percnopterus } \\
\mathrm{n}=1\end{array}$ & Aldicarb & 0.01 & \\
\hline $\begin{array}{c}\text { Eurasian Eagle-Owl } \\
\text { Bubo bubo } \\
\mathrm{n}=1\end{array}$ & Carbofuran & 0.02 & Not detected in the gizzard \\
\hline $\begin{array}{c}\text { Griffon Vulture } \\
\text { Gyps fulvus } \\
\mathrm{n}=1\end{array}$ & Carbofuran & NQ & $\begin{array}{l}\text { Also detected and quantified } \\
\text { in the crop: } \\
0.27 \mathrm{mg} / \mathrm{kg}\end{array}$ \\
\hline $\begin{array}{c}\text { Marsh-harrier } \\
\text { Circus aeruginosus } \\
\mathrm{n}=1\end{array}$ & Aldicarb & 0.23 & $\begin{array}{l}\text { Also detected in the gizzard: } \\
\qquad 0.18 \mathrm{mg} / \mathrm{kg}\end{array}$ \\
\hline $\begin{array}{c}\text { Marsh-harrier } \\
\text { Circus aeruginosus } \\
\mathrm{n}=1\end{array}$ & Aldicarb & 0.12 & Not detected in the gizzard \\
\hline
\end{tabular}

$\mathrm{NQ}=$ not quantified, detected by thin layer chromatography (TLC)

The viability of beaks and talons as samples in which to determine pesticide poisoning in vultures and more broadly in avian mortality - was discussed during a 2014 workshop that was jointly organized by the Vulture Conservation Foundation (VCF), the 
environmental branch of the government of Andalucía and Working Dogs for Conservation (WD4C) in the context of gathering conclusive evidence to mitigate the poisoning of African and Eurasian vultures. We realized during this meeting that further awareness was needed regarding the possibility of conducting toxicological analyses of avian talons and heads/beaks. We therefore urge our colleagues in Africa and Europe who encounter an avian mortality event in the field to consider collecting entire heads and talons for analysis of likely pesticides and their primary metabolites, especially given that relative to tissue samples, their recovery, storage and transportation is straightforward and requires minimal materials (Richards et al. 2014, Richards et al. 2015).

In Europe where a legal framework is being forged, and in Africa, where efforts are underway to strengthen legislation, regulatory mechanisms and investigatory/analytical capacity, failure to utilize these samples in the absence of other viable carcass components may result in pesticide residues - and deliberate poisoning incidents - being overlooked. In Africa there could also be severe health repercussions to people who consume heads or feet (Richards et al. 2015) in the context of traditional medicine or fetishism, for example in parts of western and central Africa (McKean et al. 2013, Buij et al. 2015). This is an area that requires further exploration, and that could be informed by toxicological analysis of beaks and talons. Following North American incidents of avian mass mortality related to agricultural applications, analysis of beaks and talons from carcasses too decomposed for $\mathrm{AChE}$ or tissue analysis could nonetheless provide additional information that would not otherwise be compiled.

Simple but comprehensive protocols related to sample collection, storage and analysis, as well as follow-up support, are available upon request.

\section{Acknowledgements}

As always, we commend the wildlife agents working under the auspices of the Estrategia Para el Control del Veneno who collect these samples with the utmost care, and the members of the canine detection unit who help bring to light the evidence that is collected. The support of Dr. Iñigo Fajardo, Dirección General Gestion Medio Natural, Junta de Andalucía, is gratefully acknowledged. Special thanks to Jose Rafa Garrido from Medio Ambiente y Agua de Andalucía, Imperial Eagle Monitoring 
Programme. We also extend our significantly improved by comments sincere gratitude to CAD personnel from Darcy Ogada, André Botha and for their usual professional two anonymous reviewers.

involvement. This manuscript was

Keywords: talon, beak, vulture, raptor, pesticide, poisoning, forensic

\section{References}

BirdLife International. 2013. Species factsheet: Aegypius monachus. Downloaded from http://www.birdlife.org on 2 February 2017.

BirdLife International.2013. Species factsheet: Milvus milvus. Downloaded from http://www.birdlife.org on 2 February 2017.

BirdLife International. 2015. Species factsheet: Neophron percnopterus. Downloaded from http://www.birdlife.org on 2 February 2017.

Buij, R., Nikolaus, G., Whytock, R. Ingram, D. J. \& Ogada, D. 2015. Trade of threatened vultures and other raptors for fetish and bushmeat in West and Central Africa. Oryx 8: 1-11.

Fajardo, I., Ruiz, A., Zorrilla, I., Valero, A. Fernandez, I., Saez, E., Molino, F. M. \& Olivares, J. 2012. Use of specialised canine units to detect poisoned baits and recover forensic evidence in Andalucía (southern Spain). In: Carbofuran and wildlife poisoning: global perspectives and forensic approaches (Ed: N. L. Richards). John Wiley and Sons, Ltd, United Kingdom. Pp 147-155.

Fajardo, I. \& Zorrilla, I.. 2016. Manual de Técnica Policial Ambiental Identificación in situ de causas de muerte en fauna silvestre (Environmental police techniques used to identify causes of wildlife mortality in situ). Consejeria de Medio Ambiente y Ordenacion del Territorio, Seville.

Henny, C., \& Elliott, J.. 2007. Toxicology. In: Raptor research and management techniques. Second Edition. (Eds: D.M. Bird \& K.L. Bildstein). Raptor Research Foundation, Hancock House Publishers, USA \& Canada. Pp 329-350. 
Hill, E. F. \& Fleming, W. J. 1982. Anticholinesterase poisoning of birds: Field monitoring and diagnosis of acute poisoning. Environmental Toxicology and Chemistry 1: 27-33.

McKean, S., Mander, M., Diederichs, N., Ntuli, L. Mavundla, , K., Williams, V. \& Wakelin, J. 2013. The impact of traditional use on vultures in South Africa. Vulture News 65: 15-36.

Mineau, P., Porter, S. \& Meteyer, C. U. 2012a. Carbofuran: toxicity, diagnosing poisoning and rehabilitation of poisoned birds. Pages 19-38 in N.L. Richards [ED.], Carbofuran and wildlife poisoning: global perspectives and forensic approaches. John Wiley and Sons, Ltd., United Kingdom.

Mineau, P., Lyon, L. \& McMillan, S.. 2012b. Impacts of carbofuran on birds in Canada and the United States. In: Carbofuran and wildlife poisoning: global perspectives and forensic approaches (Ed: N. L. Richards). John Wiley and Sons, Ltd, United Kingdom. Pp 208-250.

Muñoz-Arnanz, J. \& Jiménez , B. 2011. New DDT inputs after 30 years of prohibition in Spain. A case study in agricultural soils from south-western Spain. Environmental Pollution 159: 3640-3646.

Ogada, D. 2014. The power of poison: pesticide poisoning of Africa's wildlife. Annals of the New York Academy of Sciences 1322: 1-20.

Ogada, D. L., Shaw, P., Beyers, R. L., Buij, R., Murn, C., Thiollay, J-M., Beale, C. M., Holdo, R. M., Pomeroy, C., Baker, N., Krüger, S. C., Botha, A., Virani, M. Z., Monadjem, A. \& Sinclair, A. R. E. (2015). Another continental vulture crisis: Africa's vultures collapsing toward extinction. Conservation Letters 9: 89-97

Odino, M. 2012. Measuring the conservation threat that deliberate poisoning poses to birds in Kenya: The case of pesticide hunting with Furadan in the Bunyala Rice Irrigation Scheme. In: Carbofuran and wildlife poisoning: global perspectives and forensic approaches (Ed: N. L. Richards). John Wiley and Sons, Ltd, United Kingdom. Pp 53-70.

Otieno, P.O., Lalah, J. O., Virani, M. Z., Jondiko, I. O. \& Schramm, K. W.. 2010. Carbofuran and its toxic metabolites provide forensic evidence for 
Furadan exposure in vultures Gyps africanus in Kenya. Bulletin of Environmental Contamination and Toxicology 84: 536-544.

Richards, N. L., Hall, S. W., Harrison, N. M., Gautam, L., Scott, K. S., Dowling, G., Zorrilla, I. \& Fajardo, I. 2014. Merging wildlife and environmental monitoring approaches with forensic principles: Application of unconventional and non-invasive sampling in ecopharmacovigilance. Journal of Forensic Research 5: 228.

Richards, N.L., Zorrilla, I., Fernandez, I., Calvino, M., Garcia, J. \& Ruiz, A. 2015. A preliminary assessment of the palate and tongue for detecting organophosphorus and carbamate pesticide exposure in the degraded carcasses of vultures and other animals (and Supplemental Information). Vulture News 68: 32-51.

Vyas, N.B., Span, J. W., Hulse, C. S., Torez, M., Williams, B. I. \& Leffel, R. 2003. Decomposed gosling feet provide evidence of insecticide exposure. Environmental Monitoring and Assessment 98: 351-361.

Vyas, N.B., Spann, J. W., Hulse, C. S., Bauer, W. \& Olson, S. 2005. From the field: Carbofuran detected on weathered raptor carcass feet. Wildlife Society Bulletin 33: 1178-1182.

Zoun, P.E.F. \& Spierenburg, T. J. 1989. Determination of cholinesteraseinhibiting pesticides and some of their metabolites in cases of animal poisoning using thin-layer chromatography. Journal of Chromatography 462: 448-453.

$* * * * * *$ 